\title{
KONSEP PEMBERDAYAAN MASYARAKAT BANTARAN SUNGAI DENGAN KEGIATAN BUDIDAYA KERAMBA IKAN ARUS DERAS (Kasus Sungai Pesanggrahan di DKI Jakarta)
}

\author{
Rizky Muhartono ${ }^{1, *}$ dan Nurlaili ${ }^{2}$ \\ ${ }^{1}$ Balai Besar Riset Sosial Ekonomi Kelautan Perikanan. Badan Riset Sumberdaya Manusia- \\ Kementerian Kelautan Perikanan \\ ${ }^{2}$ Sekolah Pascasarjana Program Doktor Program Studi Sosiologi Pedesaan, Institut Pertanian Bogor \\ * Email: rizky_san@yahoo.com
}

\section{RINGKASAN}

Jakarta merupakan daerah dengan wilayah yang dilintasi 13 sungai. Namun demikian, pada sungai-sungai tersebut kerap dijumpai sampah. Salah satu penghasil sampah di sungai (diduga) berasal dari limbah domestik masyarakat yang tinggal di bantaran sungai. Permasalahan utama yang diangkat adalah bagaimana masyarakat bantaran sungai peduli dengan tidak membuang sampah ke sungai. Salah satu tema penting yang dapat dilakukan sebagai konsep pemberdayaan masyarakat bantaran sungai adalah bersahabat dengan sungai. Program ini tidak bertujuan untuk mencegah banjir yang datang ke Jakarta tetapi konsep ini dimunculkan sebagai jawaban untuk melawan kebiasaan masyarakat bantaran sungai yang sudah terlanjur menganggapnya sebagai lahan milik pribadi sehingga dibolehkan membuang sampah di sungai. Memahami karakteristik masyarakat dan individu dengan mempertimbangkan unsur budaya dan norma setempat menjadi penting, sehingga hambatan program berupa rendahnya saling percaya dan minimnya inovasi dan kreativitas bisa diatasi.

Kata kunci: masyarakat, pemberdayaan, sampah, sungai

\section{PERNYATAN KUNCI}

- Permasalahan sampah di Sungai Jakarta masih menjadi pekerjaan rumah bagi pemerintah

- Keberadaan sampah masih kerap dijumpai di tepian atau pada aliran sungai

- Sebagian masyarakat bantaran kali belum mengganggap sungai sebagai properti yang harus dijaga kelangsungannya. Sebagian masih membuang sampah ke sungai
- Menjaga sungai harus melibatkan banyak pihak dan tidak hanya berbasis instruksi dari pihak yang berwenang

- Masyarakat bantaran kali memiliki potensi dilibatkan dalam kegiatan pemberdayaan sungai

\section{REKOMENDASI KEBIJAKAN}

- Pemerintah DKI perlu membuat terobosan kebijakan pemberdayaan masyarakat bantaran sungai dengan konsep bersahabat dengan sungai. 
Konsep ini dimunculkan sebagai jawaban untuk melawan kebiasaan masyarakat bantaran sungai yang sudah terlanjur menganggapnya sebagai lahan milik pribadi (membuang sampah di sungai).

- Kebijakan ini perlu dilakukan dengan pendekatan transdisiplin ilmu pengetahuan dengan melibatkan berbagai instansi terkait yang memiliki kewenangan dan pengetahuan (konsep dan praktek) tentang masyarakat lokal, sungai dan komoditas budidaya.

\section{PENDAHULUAN}

Jakarta merupakan salah satu propinsi yang banyak dikelilingi oleh sungai/kali. Setidaknya terdapat 13 sungai yang melintasi dan membelah Jakarta. Sungaisungai tersebut di antaranya adalah Sungai Ciliwung, Sungai Krukut, Sungai Pesanggrahan. Dahulu kala, sungai/kali difungsikan sebagai salah satu media transportasi yang dilakukan oleh sebagian warga Jakarta terutama dilakukan oleh para petani untuk mengirimkan hasil panennya untuk dipasarkan di Jakarta. Saat ini, fungsi sungai/kali di Jakarta sudah jauh berubah, tidak difungsikan sebagai sarana transportasi tetapi hanya difungsikan sebagai tempat mengalirnya air dan pembuangan limbah domestik rumah tangga.

Pada saat musim kemarau sungai dianggap sahabat oleh warga Jakarta karena terlihat sangat jinak dengan air yang mengalir tenang, tetapi kondisi ini berubah dengan cepat pada saat musim hujan, dimana sebagian besar warga Jakarta menjadikan sungai sebagai musuh bersama karena kondisinya yang tidak dapat menampung air sehingga menyebabkan banjir. Bahkan, banjir tidak hanya melanda daerah yang dialiri sungai melainkan mampu menjangkau wilayah yang dahulunya tidak pernah mengenal kata "banjir".

Jika dilihat lebih mendalam permasalahan banjir di Jakarta bukan hanya disebabkan tidak berfungsinya sungaisungai. Permasalahan banjir sangat kompleks, salah satu faktornya adalah disebabkan oleh perilaku negatif manusia. Wilayah puncak dahulu memiliki berfungsi utama sebagai daerah resapan air, namun kondisi ini disulap menjadi vila-vila mewah yang dibangun tanpa mengindahkan fungsi lahan. Salah satu penyebab adalah lemahnya pengawasan dan pencegahan yang dilakukan aparat terkait.

Banjir juga dapat diakibatkan sebagai akumulasi tindakan masyarakat yang tidak bertanggung jawab dengan cara membuang sampah ke sungai/kali sehingga menyebabkan pendangkalan arus (Arifin et al, 2014). Sebagian besar masyarakat yang tinggal di bantaran kali menggunakan sungai/kali sebagai tempat sampah yang panjang dan mengalir sehingga sungai/kali memiliki beban yang berat yaitu sebagai 
tempat sampah. Sebagai contoh disepanjang Sungai Ciliwung atau Sungai Pesanggrahan, Warga memang mencari tempat yang praktis untuk membuang sampah. Tempat pinggir kali menjadi tujuan pembuangan sampah lantaran berada dekat pemukiman mereka (http://bataviase.co.id).

Selain permasalahan sampah, permasalahan lain yang ditemui di daerah aliran sungai adalah penyempitan badan sungai dan banyaknya bangunan liar yang menempati lahan-lahan yang dilarang untuk ditempati yang menyebabkan kondisi sungai menjadi sempit. Sebagai contoh, Sungai Pesanggrahan yang pada awalnya seluas delapan meter kini menciut menjadi dua meter saja dan volume sampah yang dihasilkan berkisar 15 truk sampah per hari (http://www.jakarta.go.id).

\section{SITUASI TERKINI}

Pemerintah DKI sebenarnya sudah memiliki komitmen preventif untuk menanggulangi permasalahan yang diderita oleh sungai (penumpukan sampah yang menyebabkan pendangkalan pada sungai) diantaranya adalah dengan melakukan pengerukan sungai, namun dikarenakan rendahnya kesadaran masyarakat dan masih melakukan kegiatan pembuangan sampah di sungai menjadikan langkah yang dilakukan oleh pemerintah daerah menjadi tidak efektif (http://www.beritajakarta.com).

Permasalahan utama yang diangkat adalah bagaimana masyarakat bantaran sungai peduli dengan tidak membuang sampah ke sungai. Salah satu tema penting yang dapat dilakukan sebagai konsep pemberdayaan masyarakat bantaran sungai adalah bersahabat dengan sungai. Program ini tidak bertujuan untuk mencegah banjir yang datang ke Jakarta tetapi konsep ini dimunculkan sebagai jawaban untuk melawan kebiasaan masyarakat bantaran sungai yang sudah terlanjur menganggapnya sebagai lahan milik pribadi sehingga dibolehkan membuang sampah di sungai. Memahami karakteristik masyarakat dan individu dengan mempertimbangkan unsur budaya dan norma setempat menjadi penting, sehingga hambatan program berupa rendahnya saling percaya dan minimnya inovasi dan kreativitas bisa diatasi (Noviandi et al, 2017; Andreas dan Savitri, 2016; Mardikanto, 1993; Bustang, 2008; ).

Setelah mengikuti program ini diharapkan masyarakat akan memiliki paradigma yang berbeda dalam memandang sungai (terjadi perubahan paradigma) sehingga tekanan ekologis yang diderita sungai akan sedikit berkurang karena masyarakat semakin peduli. Sungai akan dihargai sebagai bagian dari hidup, dimana masyarakat tersebut akan mendapatkan keuntungan secara langsung dan tidak langsung jika mereka mau memelihara kelestarian sungai. 


\section{ANALISIS DAN ALTERNATIF SOLUSI}

Pengembangan komunitas adalah salah satu metode yang tujuan utamanya untuk memperbaiki kualitas hidup masyarakat melalui pendayagunaan sumbersumber yang ada pada mereka serta menekankan pada prinsip partisipasi sosial dimana masyarakat terlibat dalam proses perencanaan, pelaksanaan, pengawasan dan evaluasi suatu program (Suharto, 2009). Pelibatan masyarakat menjadi penting guna mengetahui kondisi, kebutuhan dan sikap dan akan merasa memiliki program dan bukan hanya objek (Sumardjo dan Saharuddin, 2004).

Program pada kasus ini lebih memfokuskan kepada aspek pemberdayaan komunitas masyarakat pinggir sungai untuk meningkatkan kesadaran secara kelompok dengan mengubah persepsi masyarakat tentang sungai dan meningkatkan potensi ekonomi dari sungai dengan cara membuat keramba arus deras yang digunakan sebagai tempat memelihara ikan.

Pembuatan keramba arus deras dapat dijadikan salah satu stimulus untuk menarik perhatian dan kepedulian masyarakat terhadap sungai. Masyarakat akan dikondisikan untuk menjaga keadaan keramba dari kerusakan (terutama banyaknya sampah yang tersangkut) karena keramba berfungsi sebagai salah satu sumber penghasilan dengan ikan yang dipelihara. Dengan memelihara ikan di keramba, masyarakat diharapkan akan meningkatkan kepedulian dan mengkondisikan masyarakat di lingkungannya untuk tidak membuang sampah ke sungai.

Keramba arus deras dipilih untuk memanfaatkan kondisi arus sungai yang tetap mengalir dan memanfaatkan nutrisi (makanan ikan) yang terbawa arus sehingga ikan yang dipelihara tidak hanya mengandalkan pakan yang diberikan tetapi mendapatkan makanan alami. Keramba dibuat dari jaring berbahan kawat atau jaring berbahan nilon dan menggunakan pelampung yang terbuat dari drum plastik bekas yang dirancang menyesuaikan kondisi sungai Jakarta yang sering dilanda banjir sehingga ketika banjir datang, keramba tetap mengapung menyesuaikan dengan tingginya air.

Sungai Pesanggrahan dipilih dengan asumsi pencemaran pada sungai ini tidak separah yang terjadi di sungai-sungai yang lain. Sungai ini melintasi selatan jakarta yang banyak memiliki kawasan perumahan dan cenderung lebih sedikit jumlah pabrik yang dicurigai membuang limbah ke sungai jika dibandingkan wilayah lain, sehingga dari aspek teknis pencemaran air, ikan yang dipelihara di dalam keramba masih bisa tumbuh dan berkembang.

Jenis ikan yang dipelihara adalah ikan yang mampu hidup pada kondisi arus mengalir, rawa dan air yang keruh. Ikan lele, 
nila dan gabus sehingga tingkat kematian (mortalitas) dapat dikurangi dan masyarakat yang memelihara tidak disibukkan dengan perawatan ikan secara teknis seperti menjaga $\mathrm{pH}$ air, menjaga suhu dan penyakit yang menyerang ikan tetapi cukup merawat keberadaan keramba dan membersihkan sampah yang tersangkut.

Pada Gambar 1 dapat dilihat bahwa program ini dapat dibagi menjadi lima fase/tahapan, yaitu: penentuan lokasi, penyuluhan, pembentukkan kelembagaan, pelaksanaan program, dan evaluasi program. Pada pelaksanaan tiap fase dilakukan kegiatan monitoring dan pendampingan dengan tujuan mengawasi dan memastikan program dilaksanakan sesuai dengan kebijakan dan ketentuan yang telah disepakati bersama. Jika Ditemukan permasalahan dapat dicarikan solusi yang tepat dan cepat.

Fase pertama adalah penentuan lokasi. Proses ini didasari dengan pertimbangan bahwa lokasi tersebut harus dilewati kali pesanggrahan sehingga tujuan awal (merubah paradigma) masyarakat bantaran kali untuk menjaga kelestarian kali dapat dilaksanakan. Pertimbangan dalam penentuan lokasi yaitu merupakan kawasan padat penduduk dengan tingkat ekonomi menengah ke bawah, karena ada kecenderungan masyarakat pada tingkat ini kurang memperhatikan keberadaan kali (membuang sampah ke kali). Pertimbangan lain adalah jika lokasi dilaksanakan pada kompleks perumahan menengah ke atas, maka program menjadi tidak tepat sasaran karena salah satu tujuan program ini adalah memberikan penghasilan tambahan dengan cara memelihara ikan.

Fase kedua adalah melakukan penyuluhan/sosialisasi dengan tujuan masyarakat memiliki paradigma yang proenvironment, sehingga akan memaknai kali dengan bijaksana dan bukan sebagai tempat sampah ataupun sumber musibah (banjir). Materi-materi penyuluhan yang disampaikan kepada masyarakat diantaranya: tentang sampah (daur ulang sampah), kepedulian terhadap lingkungan (pentingnya kali), budidaya ikan di kali menggunakan keramba jaring (pembuatan dan perawatan), dan pemasaran. Kegiatan penyuluhan menanamkan bahwa program yang dilakukan bukanlah kegiaran profit oriented sehingga diharapkan masyarakat tidak sekedar mencari bantuan modal, tetapi berdasarkan kepedulian terhadap lingkungan sehingga pada akhirnya mau melaksanakan kegiatan tanpa harus digerakkan dengan uang. 


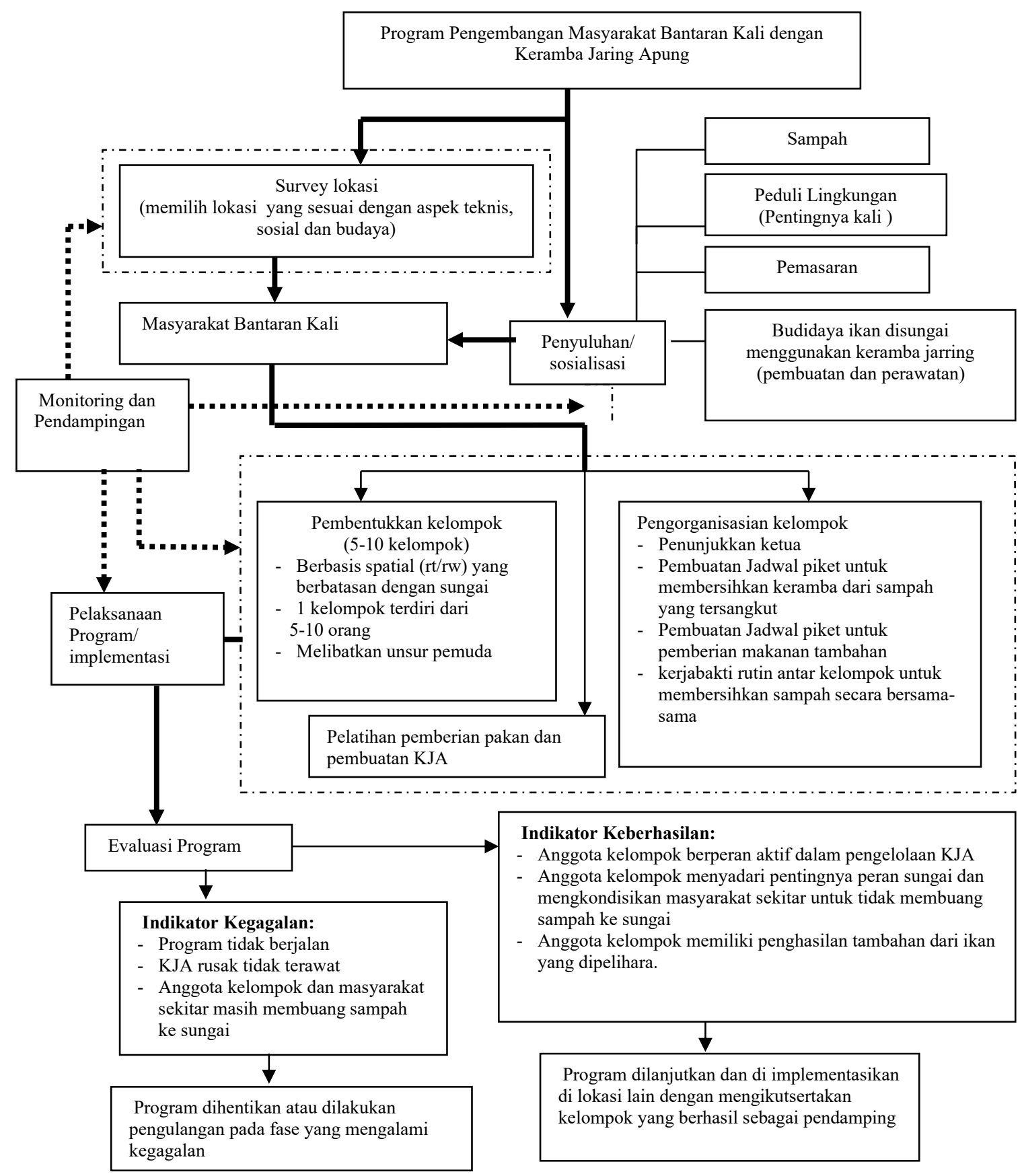

Gambar 1. Skema Program

Setelah paradigma masyarakat terbentuk dalam memandang peran kali, langkah selanjutnya adalah fase ketiga yaitu pembentukkan kelompok. Kelompok yang dibentuk didasari dengan kesamaan spatial (RT/RW) dengan tujuan memudahkan koordinasi pada saat pelaksanaannya. Satu kelompok terdiri atas 5-10 orang dengan tujuan kelompok yang dibentuk dapat bekerja dengan efektif dan memudahkan koordinasi, selain itu diharapkan tidak ada anggota yang tidak mempunyai tanggung jawab (free rider) dan hanya sekedar menjadi anggota pasif.

Unsur lain yang tidak boleh dilupakan adalah melibatkan unsur pemuda. Dalam 
hal ini generasi muda diharapkan menjadi generasi penerus yang dapat menularkan pemahaman pentingnya peran kali. Bagi generasi muda, kelompok KJA berguna sebagai wadah aktualisasi diri yang positif sekaligus sebagai langkah pengurangan peredaran narkoba dikalangan generasi muda.

Setelah kelompok terbentuk, kemudian dilakukan pengorganisasian kelompok seperti pemilihan ketua, pembuatan jadwal piket untuk memberikan pakan, jadwal piket untuk membersihkan sampah yang menyangkut maupun kerja bakti rutin antar kelompok. Dalam hal ini, program-program yang akan dilaksanakan oleh kelompok dibuat secara bottom-up berdasarkan kesepakatan dan keinginan masing-masing anggota kelompok yang sudah dimusyawarahkan. Pihak pendamping, berperan sebagai mediasi awal pada pembuatan program dan tidak memiliki kewenangan untuk menentukan program yang akan dilaksanakan pada masing-masing kelompok. diharapkan masing-masing anggota kelompok dapat bertanggung jawab terhadap keputusan yang telah dihasilkan dan mau melaksanakan dengan kesadaran sepenuh hati. Kegiatan lain yang dilakukan adalah membuat pelatihan pembuatan KJA dan mempraktekkannya secara bersama-sama diantara anggota kelompok.
Langkah selanjutnya yang dilakukan oleh pendamping program adalah menginisiasi pembentukkan wadah antar kelompok keramba jaring dengan harapan masing-masing kelompok dapat saling berkomunikasi untuk mengkonsultasikan permasalahan yang ditemui atau melakukan perancangan program yang akan dilakukan bersama.

Fase keempat adalah pelaksanaan program. Pada fase ini, berlangsung pada saat bibit ikan dimasukkan kedalam keramba sampai dengan masa panen. Lamanya pelaksanaan pemeliharaan ditentukan oleh jenis ikan yang akan dipelihara. Untuk jenis ikan lele memakan waktu sekitar 3 bulan hingga bisa dipanen, sedangkan untuk ikan nila memakan waktu sekitar 3-4 bulan.

Fase terakhir adalah evaluasi seluruh pelaksanaan program dari sejak awal (penentuan lokasi) hingga pemanenan ikan. Fase ini bertujuan untuk mengevaluasi keberhasilan atas program yang telah dijalankan. Adapun indikator keberhasilan di antaranya adalah anggota kelompok dapat berperan aktif dalam pengelolaan keramba jaring. Keaktifan anggota dapat dilihat dari kesadaran melaksanakan program yang telah disepakati bersama dan anggota kelompok bertambah kemampuannya untuk berorganisasi dan mengeluarkan pendapat. Keberhasilan yang lain adalah anggota kelompok akan semakin 
menyadari pentingnya peran sungai dan dapat mengkondisikan masyarakat sekitar untuk tidak membuang sampah ke sungai dan akan menegur jika ada anggota masyarakat yang membuang sampah sembarangan ke sungai karena akan berdampak negatif terhadap keberadaan keramba.

Jika seluruh anggota kelompok melakukan hal yang sama (menegur jika ada warga yang membuang sampah ke sungai) maka pada gilirannya akan menjadi sebuah gerakan sosial untuk tidak membuat sampah ke kali. Indikator keberhasilan lain adalah anggota kelompok memiliki penghasilan tambahan dari ikan yang dipelihara sehingga dapat membantu perekonomian keluarga. Jika program yang dilaksanakan menunjukkan keberhasilan maka program tersebut akan dijadikan contoh untuk membuat kegiatan serupa di lokasi yang berbeda dan menjadikan kelompok tersebut sebagai kelompok pendamping untuk menularkan keberhasilan yang telah dilakukan sehingga jika ada masyarakat yang meremehkan pelaksanaan program ini akan berubah dan memiliki paradigma yang sama.

Jika evaluasi program yang dilakukan menunjukkan indikator kegagalan, seperti : Program tidak berjalan, keramba jaring yang telah dibuat rusak tidak terawat, anggota kelompok dan masyarakat sekitar masih membuang sampah ke sungai dan berdasarkan hasil evaluasi tidak akan berhasil diterapkan maka kegiatan program dapat dihentikan. Namun, jika kegagalan didasarkan karena faktor teknis dan alam seperti ikan yang dipelihara masih terlalu kecil sehingga tingkat mortalitas tinggi atau mati karena ketidak sesuaian kondisi air ataupun keracunan limbah dan masih terlihat potensi perbaikan, maka program akan tetap dilaksanakan dengan berfokus memperbaiki fase yang mengalami kegagalan.

Jika kematian ikan yang terjadi karena limbah pabrik, maka kelompok dapat memberikan tekanan kepada pihak terkait untuk lebih mengawasi dan memperhatikan pembuangan limbah yang dilakukan oleh pabrik-pabrik dan memberikan sanksi yang tegas jika ada pabrik yang terbukti membuang limbahnya ke sungai. Dalam hal ini kelompok-kelompok tersebut dapat difungsikan sebagai pemberi informasi jika terjadi pembuangan limbah di sungai dan pihak terkait dapat menindaklanjuti jika ada laporan dari kelompok.

\section{REFERENSI}

Andreas, Savitri, E. 2016. Peranan Pemberdayaan Ekonomi Masyarakat Pesisir dan Modal Sosial Dalam Meningkatkan Kesejahteraan di Kabupaten Meranti dan Rokan Hilir. Universitas Riau Press.

Arifin, H.S., Kaswanto, R.L. Arifin, N.H.S., 2014. Manajemen Lanskap Riparian Sungai Ciliwung Berbasis Pemberdayaan Masyarakat dalam Mengatasi Banjir di Wilayah Hilir. 
Seminar Hasil-hasil Penelitian PPM IPB.

Bustang. 2008. Potensi Masyarakat dan Kelembagaan Lokal dalam Pemberdayaan Keluarga Miskin Pedesaan di Kabupaten Bone. Disertasi. Program Pasca Sarjana. Departemen Komunikasi dan Pengembangan Masyarakat. Institu Pertanian Bogor

Mardikanto, T. 1993. Penyuluhan Pembangunan Pertanian. Surakarta (ID): Sebelas Maret University Press.

Noviandi, T. U. Z., Kaswanto, R. L., Arifin, H. S. 2017. Riparian Landscape Management in the Midstream of Ciliwung River as Supporting Water Sensitive Cities Program with Priority of Productive Landscape. In IOP Conference Series: Earth and Environmental Science 91 (1). IOP Publishing.

http://bataviase.co.id/detailberita10293903.html

http://www.jakarta.go.id/v22/berita/inde x.php?idm $=$ \&jns $=1$ \&idkb $=1$ \&id $b$ $\underline{\text { erita }=2089}$

http://www.beritajakarta.com/2008/id/be rita detail.asp?nNewsId $=36311$

Suharto, E. 2009. Membangun Masyarakat Memberdayakan Rakyat. Kajian Strategis Pembangunan Kesejahteraan Sosial dan Pekerjaan Sosial. Penerbit Refika AditamaBandung.

Sumardjo dan Saharuddin, 2004. Metodemetode Partisipatif dalam Pengembanagn Masyarakat Model SEP -523. Departemen Ilmu-Ilmu Sosial Ekonomi. Fakultas Pertanian IPB dan Sekolah Pasca Sarjana IPB. 